\title{
Acceptance Level of Faculty Members in Utilizing Educational Technology Tools
}

\author{
Farhad Balash, Zhang Yong, and Baharin Bin Abu, Member IACSIT
}

\begin{abstract}
Educational technology as a catalyst for teaching-learning process has been urged to use in academics' activities. Every educational technology tool has its own challenges and constraints for acceptance from users; although, the application of these tools are unavoidable. Thus, the intention of the study is to explore the main factors affecting educational technology acceptance in faculty members' teaching duty in one iranian university, shahid beheshti. All the respondents include Assistant, Associate and Professors those how are faculty members at university with over 5 years teaching experience. The faculty members clarified two main factors affecting their adoption and acceptance of educational technology for teaching in their class; institutional support, and training and mentoring. These factors elicited from their narratives through interview. Eventually, in line with the findings, faculty members' development in the domain of teaching as their main duty among teaching, research, and administrative duties could be improved by considering the emergent factors in utilizing new educational technology. Likewise, evidences from the study could be essential for policy makers, technology designers and administrators in higher education institutions and universities.
\end{abstract}

Index Terms-Faculty members, Educational Technology, Professional Development, Teaching

\section{INTRODUCTION}

Interconnection of two entities, technology and learning, has appeared as a new phenomenon. And the expectations, over the years, to the qualitative potential of this phenomenon for academic atmosphere have been soaring [1], [2], [3], [4], [5] and learning through technology are treated as a global reality which is presenting new educational paradigm. This paradigm entails challenges to both macro- and microstates [5], so the impact of technology in learning, and cultivating learning process of good quality has been recommended for decades as a controversial issue [6].

Universities as the learning organizations have had remarkable attention to utilizing state-of-art technologies to facilitate their own progress, particularly in the teaching learning domain [7]. Teaching is one of the aged issues at universities as a crucial duties of faculty members among all duties; teaching, research, and administrative. Faculty members have been looking for the ways and methods to prevail over their teaching task. Among the ways to conquer in teaching educational technologic tools from 1950 has been

Manuscript received October 25, 2011; revised November 30, 2011.

Authors are with Universiti Teknologi Malaysia, Malaysia (e-mail: farhad_balash@yahoo.com, 403270546@qq.com, Baharin@utm.my; tel.:+60136129652) brought to serve teaching improvement as the applicable mediators at educational institutions. During the decades implicitly and explicitly lots of ups and downs have occurred for faculty members. Virtually, academics are reluctant to implement educational technology for teaching process because it is stressful and challengeable [8]. Based on adult education principles every new learning device and context could generate pressure condition for adults and faculty members as the matured individuals with their own specific backgrounds cannot adapt with educational technologic tools easily, unless it is related to their needs, interests, and previous knowledge. Although lecturers have been striving to use different educational technologies, the applications of educational technical tools are not efficient and effective enough in higher education institutions. In addition, educational apparatuses are used less for instructional purposes while, used more often for research and administrative affairs by lecturers [9]. Faculty members prefer technologic tools for searching, submitting, and managerial affairs and a few of them care about teaching-learning matters.

Some salient and meaningful researches show that purchasing updated and complex educational technologies such as soft wares and hard wares without commensurate support for faculty members to let them know how to apply in their real situation of teaching aspect cannot be instrumental, unless these apparatuses are injected into their errand and routine activities of teaching in a simple and acceptable ways [10], [11], [12]. They do not accept complex and timely tools which consequently need hard time consuming training classes. They rather use those educational technologic tools which could be applied in effortless and trouble-free manner. On balance, the need to find efficient and effective approaches to motivate, support, and equip faculty members with the proper competencies and skills to integrate educational technological tools into teaching process is critical and fundamental. These approaches are required to be raised from faculty members' perceptions as the last users of educational technological tools. So convergence of faculty members' notions could assist to clarify the acceptance level of them in their specific context with respect to faculty members' individual differences. Hereupon, the affecting factors as the fundamental elements on faculty members' acceptance level of technological tools for their teaching -learning activities would be topical and fair in order to enhance and improve efficiency and effectiveness.

Some studies alluded to various identified factors, the factors include institution support, leadership and effective training and development programs and resources which are all generic items for faculty members to adopt their teaching 
with educational technological tools [13], [14], [15], [16].

Moreover, faculty members' beliefs and skills are crucial for utilizing educational technologies in their teaching activity [13], [14], [15], [17]. Likewise, other personal factors such as attitude, propensity, commitment and some external factors like training directions, investing, resources, and institutional support in seamless manner affect the lectures potentiality to integrating educational technologies in their teaching context [10], [17]. Beside this, other notions come into discussion that lecturers accept special educational technological tools because of other perceptions not in accordance with their actual needs [18], [19].

Sustainably, integrating educational technological tools into teaching activity requires constructive professional development strategies such as effective mentoring and in-service training [8], [10]. This integration is like a connector bridge, whereby a trite and less effective approach of teaching transfer to more effective one. Therefore, it is the way of change along with many constraints, which some basic principles should be taken into account for fulfilment.

\begin{tabular}{|c|c|c|}
\hline $\begin{array}{l}\text { Types } \\
\text { Items }\end{array}$ & Known Factors & Experts \\
\hline \multirow{6}{*}{ Personal/Internal Factors } & \multirow{4}{*}{$\begin{array}{l}\text { Attitude, Propensity, } \\
\text { Commitment, }\end{array}$} & $\begin{array}{l}\text { Frank, Zhao, \& } \\
\text { Borman (2004) }\end{array}$ \\
\hline & & $\begin{array}{l}\text { Choudrie\& } \\
\text { Dwivedi (2005) }\end{array}$ \\
\hline & & $\begin{array}{l}\text { Cushman \& Klecun } \\
\text { (2006) }\end{array}$ \\
\hline & & $\begin{array}{l}\text { Saade, } \\
\text { Nebebe,\&Tan } \\
(2007)\end{array}$ \\
\hline & \multirow[b]{2}{*}{ Beliefs, Skills } & $\begin{array}{l}\text { Hagenson \& Castle } \\
\text { (2003) }\end{array}$ \\
\hline & & $\begin{array}{l}\text { Saade, } \\
\text { Nebebe,\&Tan } \\
(2007)\end{array}$ \\
\hline \multirow{7}{*}{$\begin{array}{l}\text { Organizational/External } \\
\text { Factors }\end{array}$} & \multirow{4}{*}{$\begin{array}{l}\text { Institutional support, } \\
\text { leadership, effective } \\
\text { training and } \\
\text { development } \\
\text { programs, resources }\end{array}$} & $\begin{array}{l}\text { Frank, Zhao, \& } \\
\text { Borman (2004) }\end{array}$ \\
\hline & & $\begin{array}{l}\text { Choudrie\& } \\
\text { Dwivedi (2005) }\end{array}$ \\
\hline & & $\begin{array}{l}\text { Cushman \& Klecun } \\
\text { (2006) }\end{array}$ \\
\hline & & $\begin{array}{l}\text { Sherry, Billig, } \\
\text { Tavalin, Gibson } \\
(2000)\end{array}$ \\
\hline & \multirow{2}{*}{$\begin{array}{l}\text { Training Directions, } \\
\text { Investing, } \\
\text { Institutional support, } \\
\text { resources }\end{array}$} & $\begin{array}{l}\text { Hagenson \& Castle } \\
\text { (2003) }\end{array}$ \\
\hline & & $\begin{array}{l}\text { Saade, } \\
\text { Nebebe,\&Tan } \\
(2007)\end{array}$ \\
\hline & $\begin{array}{l}\text { In-service Trainings, } \\
\text { Mentoring }\end{array}$ & $\begin{array}{l}\text { Schrum, Skeele, } \\
\text { \&Grant (2002) } \\
\text { Saade, } \\
\text { Nebebe,\&Tan } \\
(2007)\end{array}$ \\
\hline
\end{tabular}

Fig. 1. Factors affecting faculty members to adopt their teaching with technological tools

Basically, based on researches it is possible to group the factors in to main categories; firstly, organizational or external factors such as institutional support, leadership and effective training and development programs, training directions, or in-service trainings, mentoring, resources, investing and secondly, personal or internal factors such as attitude, propensity, commitment, beliefs, and skills. Briefly these two series of factor demonstrated in figure1.

\section{Purpose of the Study And Questions}

New revolution in Iran's higher education to adapt educational system with ever-changing world of technology is controversial. For achieving Iran's Vision 2025 in the area of higher education changes especially in confrontation with technology all the aspects of higher education system need to adopt properly [20]. In particular, faculty members as the key element for bringing the plans into life are the strategic component to develop higher education system. Hence, without their effective participation for upgrading, imparting, and developing higher education system, especially in teaching-learning sphere, seems meager to accomplish the objectives of Iran's Vision 2025 for higher education reforms. Faculty development as a latent expression has different aspects such as professional development, outreach activities development, organizational development, personal development, and instructional development. Among these constituents professional development is the most crucial constituent according to the perceptions of universities managers and developers. Professional development encompasses three main duties for faculty members. Based on universities preferences these duties could be weighted miscellaneously. These duties or functions are teaching, research, and administrative. Teaching refers to all activities which should be done to improve basic knowledge of students or change their understanding through faculty members' competencies and knowledge in specific area of science. In the learning process to transfer knowledge, as it is mentioned in activity theory, we need an appropriate tool or tools as the mediator to accomplish the purpose of teaching which is learning. Briefly speaking, Activity Theory was rooted back to Vygotsky's work and developed by Engeström. In 1978 Vygotsky's triangular model, cultural artefacts mediate individual's interaction with the objects of the environment in order for the object to transform into an outcome. His studies concentrated to individuals as showed in figure 2 [21].

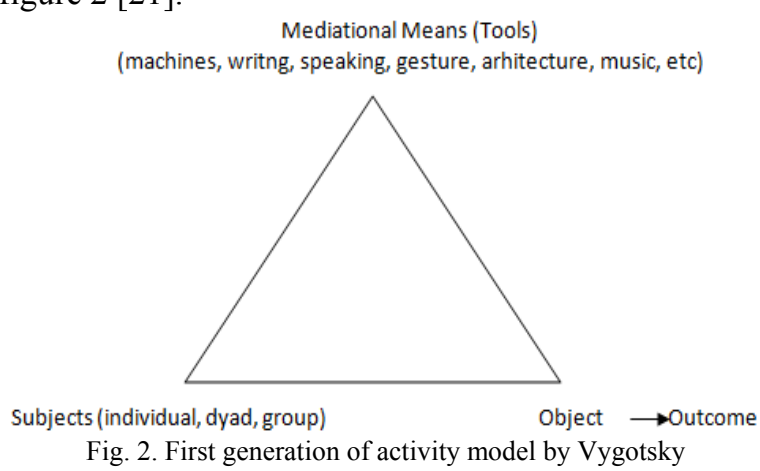

It could be possible to develop this theory for teaching -learning process. In figure 3 we can observe that if the subject is teaching by faculty members, the object is students learning as technology tools as the mediator can play a strict role to create effective learning. Faculty members by utilizing educational technology tools can expect learning as the 
outcome of their efforts (figure3). Here one latent and personal factor can impact the use of educational technologic tools which we can call it acceptance or adoption level of faculty members to learn and use educational technologic tools.

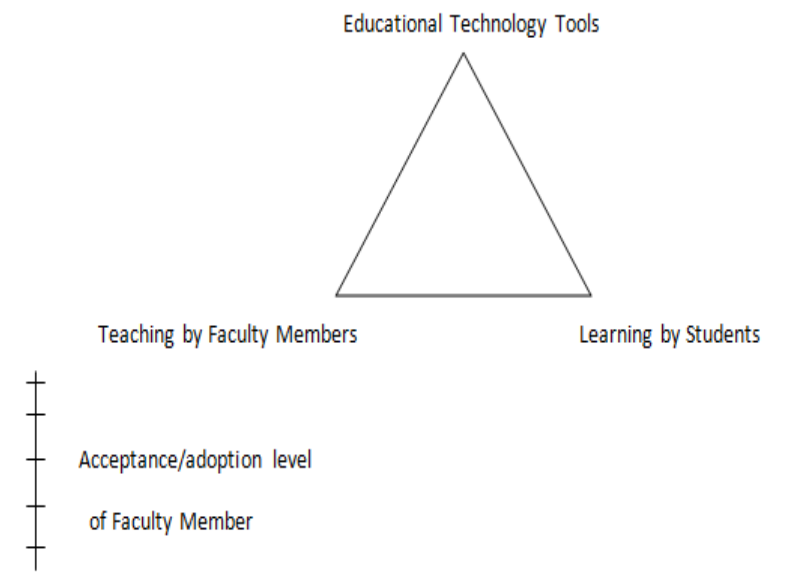

Fig. 3. Developed activity theory regarding faculty members' adoption

Therefore, In order to optimize faculty members for adoption and acceptance for new educational technologies, the first step should be heeded on identifying factors affecting faculty members' adoption of educational technology-based tools for teaching, which is the utmost objective of the investigation. Naturally in order to determine the pointed objective two questions were designed to explore from faculty members; (a) how would you describe your background in the line with integrating educational technological tools in teaching activity? (b) What are the main factors in utilizing new educational technological tools in teaching?

\section{Methodology And Data AnAlysis}

To answer research questions data from 29 faculty members were collected. Faculty members were faculty members of Shahid Beheshti University in Iran. A snowball sampling technique was conducted to collect narrative data and data were analyzed through qualitative approach of content \& narrative analysis. Researchers read through 29 narratives and examined the qualitative data for themes. These 29 respondents were from various disciplines including academic and technology leadership. 8 Professors, 13 Associate Professors, and the rest Assistant Professors, among the Assistant Professors nine were engaging in ICT affairs at university. According to literatures, two main themes were considered for analyzing all narratives; institutional support, training and mentoring.

\section{A. Institutional Support}

Information from respondents based on their experiences demonstrated some challenges which were identified as the noticeable constraints to integrating educational technological tools in teaching process. Faculty members indicated certain points such as unclear policy and planning of using these tools by departments and policy makers, lack of determined time to learning and applying new educational technology-based tools, no attention from the heads toward allocating and designing remuneration system for using the tools, and conducting explicit evaluation method for monitoring and rectifying methods of teaching, based on new educational technologies. Also many of the respondents complained recent progress system of faculty members which mostly focuses on research and there is no quality-oriented measurement for teaching in higher education system. Moreover faculty members emphasized on the quality of resources such as upgraded hardwares and state-of-art softwares and tools availability (Figure.4).

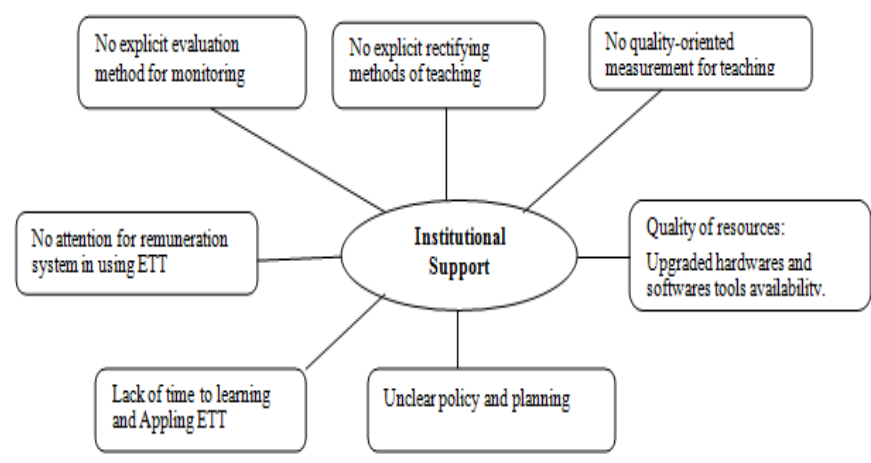

Fig. 4. Institutional factors elicited from faculty members perceptions

\section{B. Training and Mentoring}

Many respondents emphasized on planning for continuous training regarding to acquiring and reviewing new educational technological tools. They believed training could not be narrowed in faculty or their own university. They appealed for dynamic opportunities, for instance in the place of producer companies, other educational institutions, and observing peers. In addition, faculty members indicated that training should be arbitrary and developers should consider an efficient and effective mentoring program in this context. Faculty members also mentioned the mentoring programs for mentoring teaching, based on new educational technological tools should be very meticulous and soft in designing and conducting, because utilizing these tools brings some sorts of stresses and tensions, let alone being under the monitoring of others. Therefore, the betterment of the procedure needs to provide safe and sound circumstances (Figure 5)

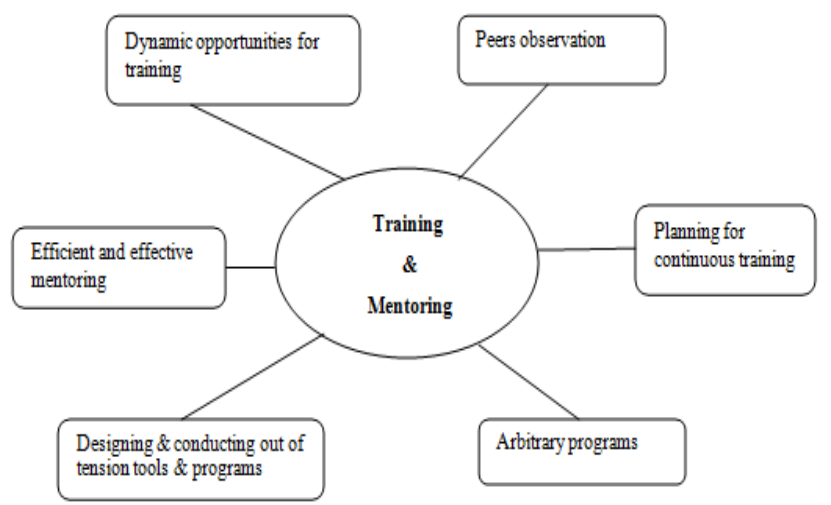

Fig. 5. Training and Mentoring factors elicited from faculty members perceptions

\section{RECOMMENDATION}

Implementing a program in higher education institutions demands strategic and comprehensive planning which should be coincided with current state and ideal state of the 
institutions based on actual and real needs. So comprehensive needs assessment and unbiased feasibility assessment is necessary for implementing and integrating educational technology tools for teaching. Therefore, not only faculty members as the main users, also other beneficiaries have to engage for identifying actual needs and shortcomings. According to findings from analyzing narratives, integrating educational technological tools to teaching by faculty members, needs strategic planning and flexibility in three dimensions; policy makers and heads, faculty members' personal attitudes and skills, and students' acceptance. In Addition, establishing the education technology office to lead faculty members for updating and supporting is critical and significant. The following figure 6 briefly depicts the study recommendation according to analyzing respondents", notions.

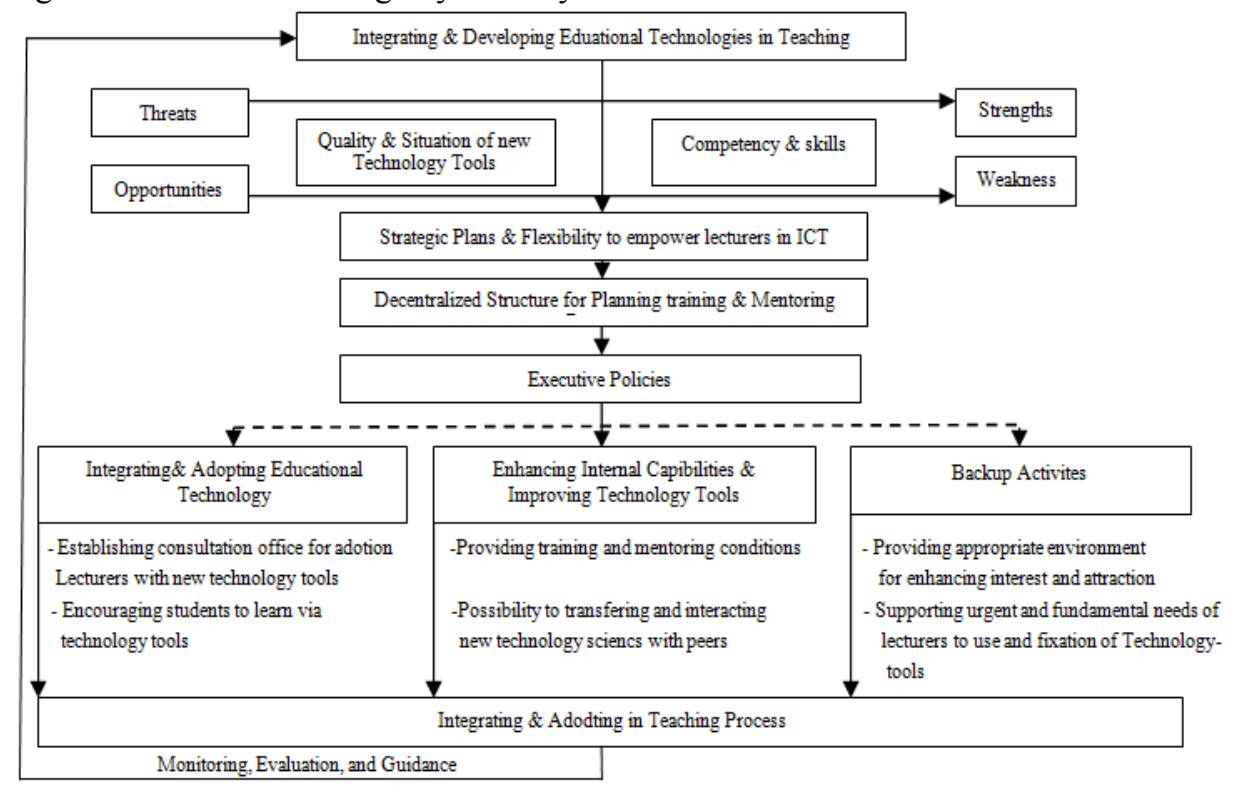

Fig. 6. Executive policy for implementing educational technology tools in teaching

\section{CONCLUSION}

According to faculty members' narratives integrating educational technological tools in teaching cannot be only confined in faculty members' internal factors such as habits, attitudes, and beliefs. Some factors also are affected the adoption process externally such as departmental policies and programs, updated and upgraded resources, mentoring, training, rewarding, salary increment, and quality evaluation system. These external and internal factors could be instrumental and constructive to pursue faculty members for utilizing educational technologies in their classroom activities. The actual beliefs of faculty members in the effectiveness of educational technology tools can appeal students' attention to a better understanding; hence, students will reaction positively to faculty members and automatically the circle of development is going to be occurred. All in all higher education organizations should strive to conduct dynamic and seamless policy for implementing state-of-art educational technology tools in teaching process.

\section{ACKNOWLEDGMENT}

The authors would like to thank all those who contributed toward making this research successful. Also, we would like to thank to all the reviewers for their insightful comment. This work was sponsored by the Research Management Unit, Universiti Teknologi Malaysia.

\section{REFERENCES}

[1] B. Collis, Tele-learning in digital world: The future of distance learning, London: International Thomson Publication, 1996.
[2] L. Harasim,, S.R. Hiltz., L.Teles and M.Turoff. Learning networks Cambridge, MA: MIT Press, 1995.

[3] R. Mason, Globalising education. Trends and applications. London: Routledge, 1998.

[4] E. KSorensen and E.S. Takle, Collaborative knowledge building in web-based learning: assessing the quality of dialogue. The International Journal on E-learning, 2002, vol.1, no.1, pp. 28-32.

[5] D. O Murchu, and E. K. Sorensen, Enhancing learning through technology, US \& UK: Information Science Publishing, 2006.

[6] H.Waxman, Lin. M, Michko GM. (July 2007). A meta-analysis of the effectiveness of recent research on the effects of teaching and learning with technology on student outcomes, 2003. [online] available: http://www.ncrel.org/tech/effects2/

[7] M. Grabe and C. Grabe. Integrating technology for meaningful learning, 5th edn, Boston: Houghton Mifflin Company, 2008.

[8] L. Schrum, R. Skeele, M. Grant. One college of education's effort to infuse technology: a systemic approach to revisioning teaching and learning. J Res Technol Educ, 2002, vol.35, no.2, pp. 256-271.

[9] L. Cuban, Oversold and underused: computers in the classroom, Cambridge: Harvard University Press, 2001.

[10] L. Hagenson and D. Castle. The integration of technology into teaching by University College of education faculty, Crawford C, Willis DA, Carlsen R, Gibson I, McFerrin K, and Price, 2003.

[11] F. Balash, "The effect of ICT on ethical intergeneration gap". Master dissertation, Dept. Edu.., Shahid Beheshti University., Iran, 2008.

[12] J. McKenzie. ( Jan 2008). How teacher learn technology best. The Educational Technology Journal, [online] 10(6), 2001, available: http://www.fno.org/mar01/howlearn.htm.

[13] M. Cushman and E. Klecun. How (Can) non-users engage with technology: bringing in the digitally excluded? Trauth E, Howcroft D, Butler T, Fitzgerald B, Gross JD (eds) Social inclusion: societal and organizational implications for information systems, Boston: Springer., pp. 347-364, 2006.

[14] J. Choudrie and Y. K. Dwivedi. Investigating the research approaches for examining technology adoption issues. J Res Pract, 2005. vol. 1, no.1, pp.1-12.

[15] K. A. Frank, Y. Zhao, K. Borman, Social capital and the diffusion of innovations within organizations: application to the implementation of computer technology in schools. Sociol Educatio. 2004, 77.pp.148-171. 
[16] L. Sherry, S. Billig, F. Tavalin, D. Gibson. New insights on technology adoption in schools. T.H.E. Journal, 2000, vol. 27, no.7. pp. 43-46.

[17] R. G. Saade', F. Nebebe, W. Tan, Viability of the technology acceptance model" in multimedia learning environments: a comparative study, Interdiscip J Knowl Learn Objects , 2007, pp. $175-184$

[18] R. Dagada, "The impact of the technology acceptance model (TAM) in determining the success or failure of computer integrated education", Kommers P, Richards G (Eds) Proc of world conf on educational multimedia, hypermedia and telecommunications 2005. AACE, Chesapeake, pp. 1125-1129

[19] L. Sherry and D. Gibson. The path to teacher leadership. Contemp Issues Technol Teach Educ.2002, vol. 2, no. 2, pp.178-203. Available: http://www.aace.org/dl/index.cfm/fuseaction/View/paperID/10585

[20] A. Heidari. "The importance of coincidence of higher education development plans with Iran development plans", Iran National 2050
Vision Conf, Management \& Planning education \& Research Assosiation., 2006, vol. 3, pp. 226-235.

[21] Y. Engeström, Innovative Learning in Work Teams: Analyzing Cycles of Knowledge Creation in Practice. Perspectives on Activity Theory. Cambridge: Cambridge University Press, 1999.

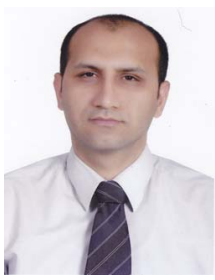

Farhad Balash was born in 1975. He is persian and is studing $\mathrm{PhD}$ at Universiti Teknologi Malaysia (UTM). His master is Adult Education and now he is doing $\mathrm{PhD}$ of Education \& Development. The main field of research is Academic Staff Development (Faculty Development). 